\title{
Review \\ The Role of Plant Hormones in the Interaction of Colletotrichum Species with Their Host Plants
}

\author{
Thomas Svoboda ${ }^{1, *(\mathbb{D}, \text { Michael R. Thon }}{ }^{2}$ and Joseph Strauss ${ }^{1}$ \\ 1 Department of Applied Genetics and Cell Biology (DAGZ), Institute of Microbial Genetics, \\ University of Natural Resources and Life Sciences, Vienna (BOKU), 3430 Tulln an der Donau, Austria; \\ joseph.strauss@boku.ac.at \\ 2 Institute for Agribiotechnology Research (CIALE), Universidad de Salamanca, 37185 Salamanca, Spain; \\ mthon@usal.es \\ * Correspondence: thomas.svoboda@boku.ac.at
}

Citation: Svoboda, T.; Thon, M.R.; Strauss, J. The Role of Plant Hormones in the Interaction of Colletotrichum Species with Their Host Plants. Int. J. Mol. Sci. 2021, 22, 12454. https://doi.org/10.3390/ijms222212454

Academic Editor: Ricardo Aroca

Received: 5 October 2021

Accepted: 15 November 2021

Published: 18 November 2021

Publisher's Note: MDPI stays neutral with regard to jurisdictional claims in published maps and institutional affiliations.

Copyright: (c) 2021 by the authors. Licensee MDPI, Basel, Switzerland. This article is an open access article distributed under the terms and conditions of the Creative Commons Attribution (CC BY) license (https:// creativecommons.org/licenses/by/ $4.0 /)$.
Abstract: Colletotrichum is a plant pathogenic fungus which is able to infect virtually every economically important plant species. Up to now no common infection mechanism has been identified comparing different plant and Colletotrichum species. Plant hormones play a crucial role in plantpathogen interactions regardless whether they are symbiotic or pathogenic. In this review we analyze the role of ethylene, abscisic acid, jasmonic acid, auxin and salicylic acid during Colletotrichum infections. Different Colletotrichum strains are capable of auxin production and this might contribute to virulence. In this review the role of different plant hormones in plant-Colletotrichum interactions will be discussed and thereby auxin biosynthetic pathways in Colletotrichum spp. will be proposed.

Keywords: Colletotrichum spp.; plant hormones; ethylene; auxin; jasmonic acid; salicylic acid; abscisic acid

\section{Introduction}

Colletotrichum spp. are opportunistic plant pathogenic fungi which are able to infect virtually every economically important plant species, causing diseases commonly referred to as anthracnose. Both monocotyledonous plants such as sorghum or maize as well as dicotyledonous plants such as strawberries, soya or stone fruits can serve as host plants [1-5]. Among the genus Colletotrichum different subspecies differ in their way of colonization as well as in obtaining nutrients. Their lifestyles range from biotrophs to hemibiotrophs to necrotrophs. Hemibiotrophic infection begins with a biotrophic phase before the pathogen switches to the necrotrophic phase, and they are therefore able to exist in the plant as endophytes [6-8]. Within the genus Colletotrichum, around 190 species are currently described which are organized into 11 species complexes and 23 singleton species [9].

For a successful infection, Colletotrichum forms appressoria to penetrate the host plant. Around 4000 genes have been found to be upregulated in the appressoria of C. gloeosporioides growing on PDA covered with cellophane and among those, 468 genes are exclusively expressed in the appressoria and not in hyphal tissue [10]. These upregulated genes can be assigned to 107 KEGG pathways including secondary metabolism and molecular transport [10]. Analysis of the transcriptome of $C$. fructicola revealed 3189 genes differentially expressed in four infection-related structures (conidia, appressoria, infected apple leaves, cellophane infectious hyphae). Among the upregulated genes, small secreted proteins, cytochrome P450 mono-oxygenases, carbohydrate-active enzymes (CAzymes) and secondary metabolite synthetases were enriched [11]. Genes encoding CAzymes potentially degrade the plant cell wall and are more abundant in the genomes of hemibiotrophic and necrotrophic pathogens than in biotrophs [12].

Rho GTPases play a crucial role in signal transduction regulating morphogenesis and differentiation. In C. gloeosporioides, disruption of $\mathrm{CgCdc} 42$ results in reduced formation 
of appressoria which are morphologically abnormal. Furthermore, $\triangle \mathrm{CgCdc} 42$ mutants exhibit hypersensitivity towards $\mathrm{H}_{2} \mathrm{O}_{2}$ and transcriptional analysis suggesting that the gene plays a role in the regulation of ROS-related genes [13]. In C. obiculare, the causal agent of cucumber anthracnose, fatty acid $\beta$-oxidation in peroxisomes is critical for the appressorial melanisation and lipolysis [14].

The main phytohormones produced upon biotic and abiotic stresses are abscisic acid (ABA), salicylic acid (SA), jasmonic acid (JA) and ethylene (ET) [15,16]. Increasing levels of JA, SA and ET upon infection indicate that these hormones primarily mediate the response upon biotic stresses [15]. On the other side ABA biosynthesis is enhanced when abiotic stresses like heat, drought, salinity or cold prevail [17,18]. Because of different interactions between hormones the stress response is not only restricted to JA, SA, ET and ABA. Auxins (IAA), gibberellins (GA) and cytokines (CK) have also been reported to play a role in the regulation of the plant defense response $[15,19,20]$. Comparative transcriptomic analysis of maize infected with $C$. graminicola revealed an accumulation of SA inducible genes as well as accumulation of transcripts involved in JA and ET signaling pathways suggesting a hormone signaling crosstalk in systemic female inflorescence inoculated with C. graminicola [21]. There are also other transcriptomic studies available where the response of different plants like Phaseolus vulgaris [22], octoploid strawberry [23] or postharvest mango fruits [24] upon Colletotrichum infection were analysed. In this review, the role of JA, SA, ET, IAA, ABA and GA in plant-pathogen interaction of different Colletotrichum spp. affecting various hosts will be discussed.

\section{Ethylene}

ET is the simplest olefin which acts in plants as a growth hormone inducing fruit ripening, flower senescence and leaf abscission [25]. Plants synthesize ET in a three-step reaction from methionine via S-adenosyl-methionine and the precursor 1-aminocyclopropane carboxylic acid (ACC) (Figure 1) [26]. Different microbes have been reported to be capable of ET production as well. While one of the microbial pathways also starts from methionine which is converted in a two-step reaction via 2-keto-4-methylthiobutyric acid catalyzed by a NADH:FeEDTA oxidoreductase [27], the other one uses 2-oxoglutarate as substrate which is directly converted to ET by the ethylene forming enzyme (EFE) [28-30].

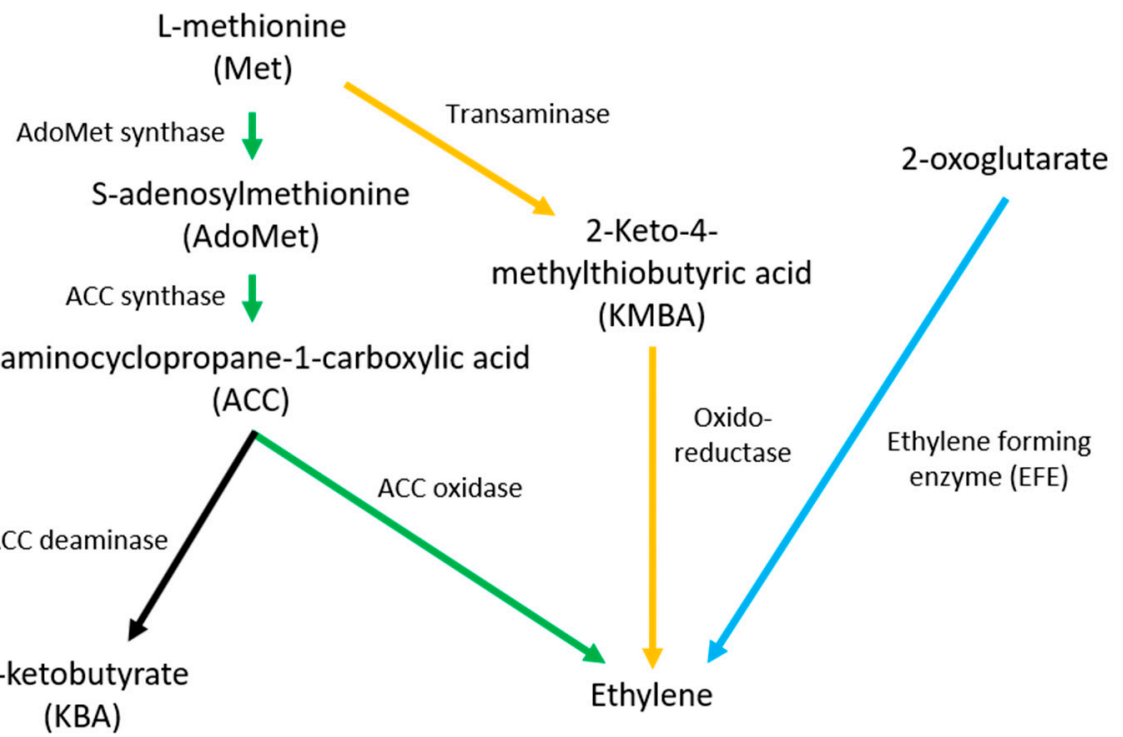

Figure 1. Ethylene biosynthetic pathways; the ACC pathway is shown in green, KMBA pathway in orange and oxoglutarate pathway in blue.

The ET downstream signaling pathway induces ethylene response factors (ERFs) triggering the stress response. One possibility to alleviate stress is the degradation of the 
immediate precursor of ET, ACC, using an ACC-deaminase which has been described in plant growth promoting rhizobacteria (reviewed by Etesami and Maheshwari [31]). Also the plant pathogenic fungus Fusarium graminearum has a functional ACC deaminase in its genome, however, this gene does not have any impact on the virulence of the fungus on the highly susceptible wheat cultivar Apogee [32]. Plant growth promoting rhizobacteria (PGPR) have been reported to show antifungal activity against various plant pathogenic fungi of the genus Fusarium, Colletotrichum, Aspergillus and Rhizoctonia by producing plant growth promoting enzymes and hormones, cell wall degrading enzymes and antibiotics [33].

In Capsicum annum cv. Punjab Lal, a chili cultivar which shows an enhanced resistance towards Colletotrichum truncatum L., a micro RNA, Can-miRn37a, interacts with ERFs and represses downstream signaling. Overexpression of Can-miRn37a in a susceptible cultivar (Arka Lohit) results in resistance by preventing fungal colonization [34]. Expression of FaGAST2, a strawberry ripening related gene, is induced by ethephon, an intracellular generator of ethylene. The expression of that gene is enhanced by oxidative stress as well as infection by Colletotrichum acutatum while overexpression caused a delay in growth of strawberry plants [35]. Ethephon induces the expression of FaGAST2 upon infection as well as the delayed growth in overexpression lines. It remains to be investigated in how far overexpression of FaGAST2 has an impact on the levels of other plant hormones like auxin.

Ethylene insensitivity has been described in Arabidopsis, wheat and barley to enhance resistance against Fusarium graminearum while ethylene overproducing lines exhibit increased susceptibility [36]. In contrast, ethylene insensitive lines of Nicotiana tabacum exhibit higher susceptibility upon inoculation with Colletotrichum destructivum compared to the wild type strain [37]. Since F. graminearum has been reported to produce ethylene on media with $20 \mathrm{mM}$ methionine supplemented [32] reduced ethylene perception results in reduced stress upon Fusarium infection. While ethylene production has been documented in Colletotrichum musae [38] as well as F. graminearum, to our knowledge C. destructivum is not able to produce ethylene to increase virulence shedding light on the opposing effect of reduced ethylene sensitivity.

The rubber tree (Hevea brasiliensis) shows different symptoms upon infection with Colletotrichum siamense and C. australisinense. This diverged pattern was traced down to a different set of pathogenicity related genes [39]. Necrosis and ethylene-inducing peptide 1-like proteins (NLPs), which can be divided in different subgroups, are produced during infiltration of the extracellular space in dicots. The majority of the NLPs in C. siamense belong to subgroup II, which do not induce necroses in the host plants while ChNLP1 of $C$. higginsianum has been shown to induce necrosis in plants [40].

\section{Abscisic Acid}

Abscisic acid, a sesquiterpenoid, acts as a plant signaling molecule mediating seed dormancy, bud growth and adaption to environmental stresses [41]. In plants, ABA is synthesized via the carotenoid biosynthetic pathway starting in the plastids. The nine-cisepoxycarotenoid dioxygenase (NCED) catalyzes the rate limiting step, the cleavage of $9^{\prime}$-cisneoxanthin or 9'-cis-violaxanthin. The resulting xanthoxin is converted to absicisic acid in the cytosol (Figure 2). Additionally, fungi also use a "direct pathway" via mevalonate where the intermediates contain no more than 15 carbon atoms [42]. The dynamics, signaling and functions of abscisic acid in plants have recently been reviewed by Chen et al. [43].

For several plant-pathogen systems, the ability of the pathogen to interfere with the host on plant hormonal level has been described [44]. Although several fungal species are not only able to synthesize ABA they are capable of sensing the hormone using specific receptors. In Aspergillus nidulans growth and metabolism can be regulated by abscisic acid. Already in the presence of $100 \mathrm{nM}$ ABA spore germination as well as fungal growth are promoted [45]. The virulence of Colletotrichum acutatum in pepper fruits is enhanced in the presence of ABA which results in increased length of lesions. Capsicum baccatum cultivars which are generally resistant to anthracnose, showed symptoms of pepper anthracnose 
upon $\mathrm{ABA}$ administration indicating that exogenous $\mathrm{ABA}$ results in the suppression of defense mechanisms of pepper fruits against anthracnose [46]. The ABA receptor, PYR/PYL family, as well as brassinosteroid insensitive 1-associated receptor kinase 1, and ABA responsive element binding factor are lower expressed in the anthracnose resistant cultivar by the factors $-25.2,-3.44,-2.73,-2.17$, respectively, compared to the parent cultivar which shows a higher susceptibility [47] indicating the contribution of ABA to virulence. The infection promoting effect of $\mathrm{ABA}$ was also reported for the infection of rice by Magnaporthe grisea in combination with cold stress [48]. The ET and the ABA pathway have been demonstrated to be connected in Arabidopsis by one gene, ETHYLENE INSENSITIVE2 (EIN2) which is also called ENHANCED RESPONSE TO ABA3 (ERA3) [49]. $\mathrm{ABA}$ interacts antagonistically with the ET pathway indicating that altered ABA levels repress the ethylene induced defense response.

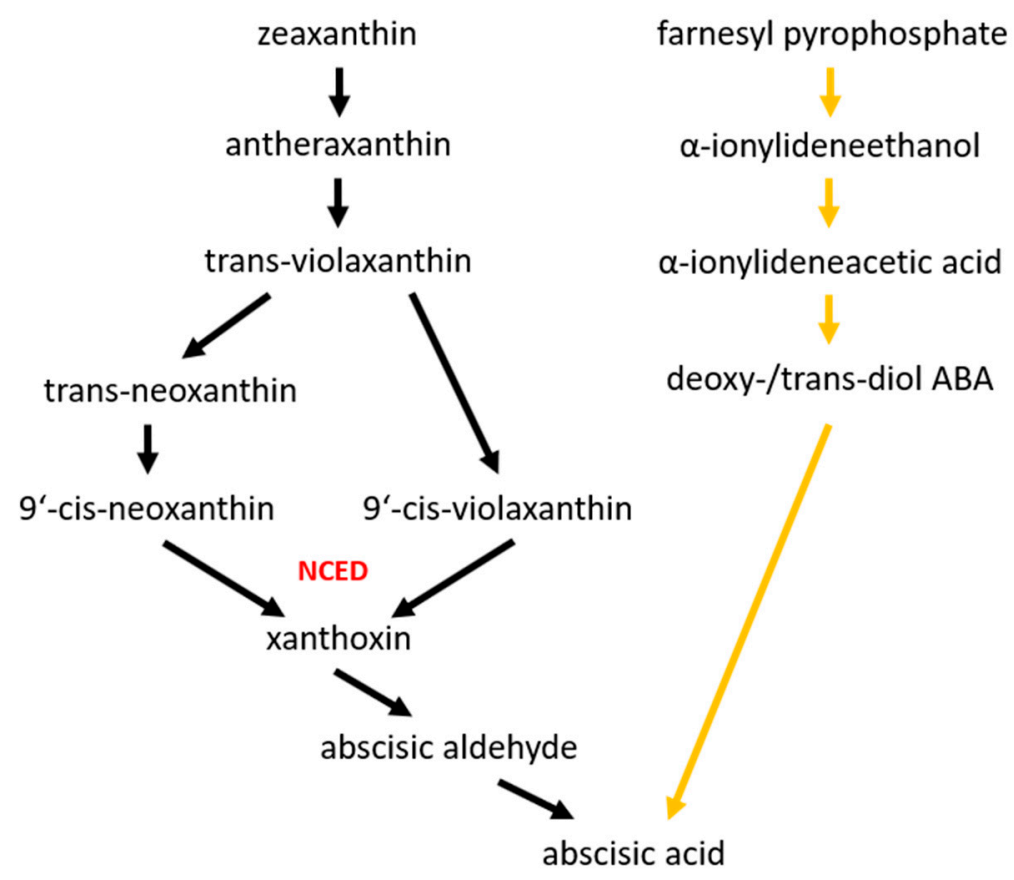

Figure 2. Abscisic acid biosynthetic pathways; the $C_{15}$ pathway is indicated by orange arrows.

Tea plants produce volatile compounds to elicit defense in undamaged tissue and neighboring plants. (E)-Nerolidol triggers a mitogen-activated protein kinase, WRKY, which acts as transcription factor and is a key compound in the abscisic acid signaling pathway. It also induces an $\mathrm{H}_{2} \mathrm{O}_{2}$ burst and increased levels of jasmonic acid and enhanced abscisic acid signaling which can increase the antioxidant capacity upon stress [50]. However, $\mathrm{ABA}$ also enhances the activity of chitin deacetylase in submerged culture by the factor of 9.5 in C. gloeosporioides resulting in a lower degree of acetylation compared to a culture lacking ABA. This resulted in a change of the acetylation of chitin which was extracted from the cell wall [51]. Chitin deacetylases (CDAs) from several Colletotrichum species have previously been expressed and characterized [52-54]. CDAs in fungi catalyze the deacetylation of chitin which leads to the formation of chitosan. This deacetylation is necessary for several fungal pathogens to increase virulence. Especially soil borne fungal pathogens have been reported to use this deacetylation as a major virulence strategy [55].

On the other side, chitinases in plants are supposed to degrade chitin, a major component of the fungal cell wall. Since most antifungal peptides are highly basic, the positive charges of chitinases might facilitate electrostatic interactions with the negatively charged phospholipids on the fungal cell surface. However, several plant pathogenic fungi secrete proteases acting against antifungal plant chitinases (reviewed by [56]). Knock down of 
CaChilII7 in pepper plants resulted not only in hypersensitivity to C. acutatum but also in attenuated defense response genes CaPR1, CaPR5 and SAR8.2 [57].

Postharvest treatment of mangoes with chitosan revealed downregulated abscisic acid and jasmonic acid levels in the peels, concomitant with a significantly extended shelf life. An infection experiment with C. gloeosporioides showed that anthracnose lesions were significantly smaller on fruits treated with chitosan compared to ones treated with acetic acid and water [58].

\section{Auxin}

Indole-3-acetic acid (IAA) which is also known as auxin acts as a growth hormone mediating apical growth and root morphology and gravitropism. Several tryptophan (TRP) dependent and TRP independent pathways have already been described in plants, algae, bacteria and fungi [59]. Indole-3-acetic acid production from TRP has been reported in C. gloeosporioides f. sp. aeschynomene in 1998. Beside auxin also tryptophol (TOL) and indole-3-acetamide (IAM) were detected in this study indicating that the IAM pathway is used [60]. Another study two years later showed as well that Colletotrichum sp. is capable of auxin production which was confirmed by NMR analysis [61]. Subsequent research revealed that $C$. acutatum is able to produce auxin from tryptophan. Beside IAA, the intermediates indole-3-acetaldehyde (IAAld), IAM as well as indole-3-pyruvic acid (IPA) were detected suggesting that different auxin biosynthetic pathways are used [62]. Also, $C$. fructicola which was isolated from coffee plants has been reported to produce auxin in vitro from TRP using the IAM pathway [63].

Based on the previously reported results the proposed auxin biosynthetic pathways in Colletotrichum emanate from tryptophan (Figure 3). While in plants the yucca pathway via IPA which is directly converted to auxin is used, Colletotrichum synthesizes IAA either using the IAM pathway (blue) or the IPA pathway via IPA and IAAld (black).

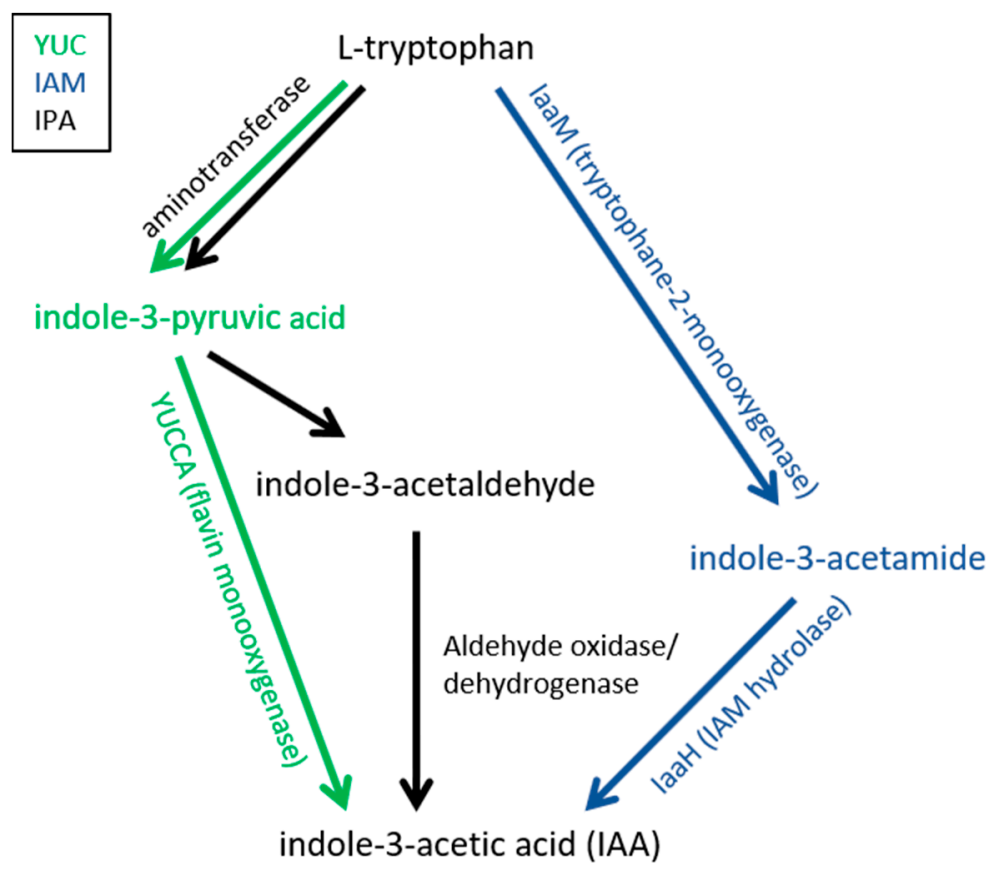

Figure 3. Tryptophan derived auxin biosynthetic pathway in plants (YUC (green)) and proposed pathways in Colletotrichum spp. (IAM (violet), IPA (black)).

IAA is often involved in plant-pathogen interaction, but it is also used by fungi to increase virulence and is therefore rather involved in plant disease susceptibility (reviewed by Chanclud and Morel [64]). Upon increasing auxin concentrations, Aux/IAA transcriptional repressors are removed from auxin response factors (ARF). Further, TIR1/AFB can 
bind to Aux/IAA transcriptional repressors inducing polyubiquitylation which further leads to proteasomal degradation. Negative feedback loops are triggered by the induced auxin responsive genes to which Aux/IAAs and the GH3 family are counted [65]. C. gloeosporioides f. sp. aeschynomene produces IAA in axenic culture using the IAM pathway and auxin is also formed at an early stage of infection indicating contribution to virulence [66]. This has been shown as well in Fusarium pathogenic to Orobanche. Introducing two genes of the indole-3 acetamide pathway in F. oxysporum and F. arthosporioides resulted in significantly higher auxin production concomitant with hypervirulence [67] supporting that fungal auxin production contributes to virulence.

A transcriptomic analysis of strawberry leaves inoculated with $C$. fructicola revealed that $24 \mathrm{~h}$ post inoculation JA and IAA levels were higher compared to the mock treatment while SA and ABA peaked after $48 \mathrm{~h}$, however, the changes were not significant at any timepoint [68]. Another study investigating the interaction between Colletotrichum camilliae and tea plants (Longing 43) demonstrated that the precursors and the intermediate products of JA and IAA biosynthesis significantly increased during the interaction, in particular when the symptoms became apparent [69]. Analysis of selected microRNAs (miRNAs) of Camellia sinensis upon C. gloeosporioides infection revealed five miRNAs which are involved in the regulation of the auxin signaling pathway. Phenylalanine ammonia lyase (PAL) and cinnamoyl-CoA reductase (CCR) were identified as target genes as well [70]. PAL deaminates L-phenylalanine into trans-cinnamic acid which can be further converted into $p$-coumaric acid by cinnamate-4-hydroxylase $(\mathrm{C} 4 \mathrm{H})$. It has been described that auxinregulated plant growth is fine-tuned by early steps in phenylpropanoid biosynthesis in terms of reduced PAL expression, while loss of $\mathrm{C} 4 \mathrm{H}$ increases the strength of the auxin response [71].

\section{Salicylic Acid}

Salicylic acid (SA) plays an essential role in the activation and regulation of responses to biotic and abiotic stresses. The biosynthesis of SA emanates from the shikimate pathway with the conversion of chorismate to isochorismate (IC) by isochorismate synthase (ICS). IC is further cleaved by pyruvate lyase (PL) releasing pyruvate and SA (Figure 4) [72].

\section{chorismate $\stackrel{\mathrm{ICS}}{\longrightarrow}$ isochorismate $\stackrel{\mathrm{PL}}{\longrightarrow}$ salicylic acid}

Figure 4. Salicylic acid biosynthesis pathway.

In contrast to auxin, Colletotrichum spp. have not been reported to be capable of producing SA. SA is involved in the resistance of tea plants to anthracnose infection. The total amount of SA (bound and free SA) is approximately twice as high in anthracnose infected tea leaves compared to healthy leaves [73]. Several studies describing the SA levels of different host plants upon Colletotrichum infection have been published.

SA is required for induction of the systemic acquired resistance (SAR) through NPR1regulated expression of pathogenesis related (PR) genes (Figure 5) [74]. Methyl salicylate (MeSA) acts over a long distance in Arabidopsis and tobacco. For activation, cleavage of MeSA by a MeSA esterase is necessary to release SA [75]. In strawberry, transcripts associated with systemic acquired resistance (SAR) and SA-mediated signaling (like FaMeSA1, a methyl salicylate esterase) pathways increase upon C. acutatum infection [76].

\section{$\mathrm{SA} \longrightarrow$ NPR1 $\longrightarrow$ PR genes $\longrightarrow$ antimicrobial defense}

Figure 5. Salicylic acid signal transduction.

The Gretchen Hagen 3 (GH3) gene family which belongs to the early auxin responsive families is ubiquitous in the plant kingdom. It is involved in modulation of hormone homeostasis and adaption to different stresses. GH3, an auxin amido synthetase, has been reported to alter the ratio of IAA and phenylacetic acid (PAA), which is also known as a 
plant growth substance, in Arabidopsis by catalyzing the formation of IAA-Asp, IAA-Glu, PAA-Asp and PAA-Glu [77]. Crossing of SA-accumulating Arabidopsis thaliana lines with IAA-overproducing mutants revealed that most of the phenotypes associated with IAAoverproduction (long hypocotyls, epinastic cotyledons, narrow rosette leaves during the adult stage and increased apical dominance) are suppressed by SA accumulation indicating a coupled regulation [78]. GH3.5 acts as positive modulator of SA signaling and plays an important role in auxin-elicited susceptibility as well. On one side GH3.5 positively regulates IAA accumulation during pathogen infection but on the other side it shows an adenylation activity on SA [79]. Expression of auxin responsive GH3-like protein is highly elevated in Citrus madurensis flowers upon C. acutatum infection while IAA amino acid hydrolase and a putative growth regulator protein do not seem to be affected [80]. It was documented that strawberries with a higher resistance towards Colletotrichum gloeosporioides show higher basal SA levels which rapidly increase upon infection. Besides, SA directly inhibited the germination of $C$. gloeosporioides conidia as well. Also exogenous application of SA four days before infection resulted in reduced symptom development [81]. SA affects plant growth under stress by stomata regulation, water relations, nutrient uptake as well as photosynthesis. Exogenous application of SA enhances resistance towards various pathogens in monocot and dicot plants (reviewed by [82]).

Furthermore, exogenous application of SA leads to enhanced resistance of cassava to $C$. gloeosporioides due to induction of syntaxin gene expression. Syntaxins generally contribute to mediate vesicle fusion in trafficking fusion by specifically forming as ternary soluble N-ethylmaleimide-sensitive factor attachment protein receptors (SNAREs) complex with the purpose to transport defense compounds to the site of microbe infection between plant cell wall and plasma membrane [83]. Anthracnose severity in cassava can be reduced by $33.3 \%$ upon SA administration under greenhouse conditions under which $\beta$-1,3-glucanase and chitinase enzyme activities were significantly higher after $24 \mathrm{~h}$ post inoculation. However, the activity decreased $48 \mathrm{~h}$ after challenging the plants with Colletotrichum gloeosporioides [84]. SA levels in different host plants upon Colletotrichum infection are shown in Table 1.

Table 1. Salicylic acid levels in different plants upon Colletotrichum infection.

\begin{tabular}{|c|c|c|c|c|c|c|}
\hline Host Plant & Cultivar/Strain & Tissue & Pathogen & SA-Levels & Time Point & Reference \\
\hline Maize & $\begin{array}{c}\text { W438 } \\
\text { lox10-3 } \\
\text { B73 } \\
\text { opr7.5 opr8.2 }\end{array}$ & $\begin{array}{l}\text { Leaf } \\
\text { Leaf }\end{array}$ & C. graminicola & $\begin{array}{l}\sim 100 \mathrm{pmol} / \mathrm{g} \mathrm{FW} \\
\sim 100 \mathrm{pmol} / \mathrm{g} \mathrm{FW} \\
<100 \mathrm{pmol} / \mathrm{g} \mathrm{FW} \\
>200 \mathrm{pmol} / \mathrm{g} \mathrm{FW}\end{array}$ & $1 \mathrm{dpi}$ & [85] \\
\hline Strawberry & $\begin{array}{c}\text { Jiuxiang } \\
\text { Benihoppe }\end{array}$ & Leaf & C. fructicula & $\begin{array}{l}0.36 \mathrm{ng} / \mathrm{mg} \text { FW } \\
0.38 \mathrm{ng} / \mathrm{mg} \text { FW }\end{array}$ & 1 hpi & [86] \\
\hline Arabidopsis & $\begin{array}{c}\text { Col-0 } \\
\text { sweet11 } \\
\text { sweet12 } \\
\text { sweet11/12 }\end{array}$ & Leaf & C. higginsianum & $\begin{array}{c}\sim 90 \mu \mathrm{g} \cdot \mathrm{m}^{-2} \\
\sim 110 \mu \mathrm{g} \cdot \mathrm{m}^{-2} \\
\sim 140 \mu \mathrm{g} \cdot \mathrm{m}^{-2} \\
\sim 190 \mu \mathrm{g} \cdot \mathrm{m}^{-2}\end{array}$ & 2 dpi & [87] \\
\hline Cucumber & Cucumis sativus & $\begin{array}{c}\text { Cotyledon inoculated: } \\
\text { Roots } \\
\text { Leaf } \\
\text { Hypocotyl } \\
\text { First leaf inoculated: } \\
\text { Roots } \\
\text { Leaf } \\
\text { Hypocotyl }\end{array}$ & C. lagenarium & $\begin{array}{c}2 \mu \mathrm{g} / \mathrm{g} \\
0.6 \mu \mathrm{g} / \mathrm{g} \\
2 \mu \mathrm{g} / \mathrm{g} \\
>2.5 \mu \mathrm{g} / \mathrm{g} \\
>3.0 \mu \mathrm{g} / \mathrm{g} \\
\sim 3.0 \mu \mathrm{g} / \mathrm{g}\end{array}$ & 6 dpi & [88] \\
\hline Tea plants & $\begin{array}{l}\text { Longjing } 43 \text { and } \\
\text { Zhenong } 139\end{array}$ & $\begin{array}{l}\text { Healthy leaves } \\
\text { Infected leaves }\end{array}$ & Colletotrichum spp. & $\begin{array}{c}\sim 8 \mu \mathrm{g} / \mathrm{g} \mathrm{FW} \\
\sim 13 \mu \mathrm{g} / \mathrm{g} \mathrm{FW}\end{array}$ & $\begin{array}{l}\text { Collected in } \\
\text { July }\end{array}$ & [73] \\
\hline Strawberry & Camarosa & $\begin{array}{l}\text { Control leaf } \\
\text { Infected leaf } \\
\text { Control leaf } \\
\text { Infected leaf }\end{array}$ & C. acutatum & $\begin{array}{c}74.42 \mathrm{ng} / \mathrm{g} \text { DW } \\
202.21 \mathrm{ng} / \mathrm{g} \text { DW } \\
52.33 \mathrm{ng} / \mathrm{g} \text { DW } \\
354.77 \mathrm{ng} / \mathrm{g} \text { DW }\end{array}$ & $\begin{array}{l}3 \text { dpi } \\
5 \text { dpi }\end{array}$ & [76] \\
\hline
\end{tabular}




\section{Jasmonic Acid}

Jasmonic acid (JA) and intermediates occur in higher plants, some lower plants as well as in some prokaryotes. The biosynthesis is a route of oxidative reactions of lipid-derived fatty acids with 12-oxo-phytodienoic acid (OPDA) as intermediate (Figure 6; reviewed in [89]).

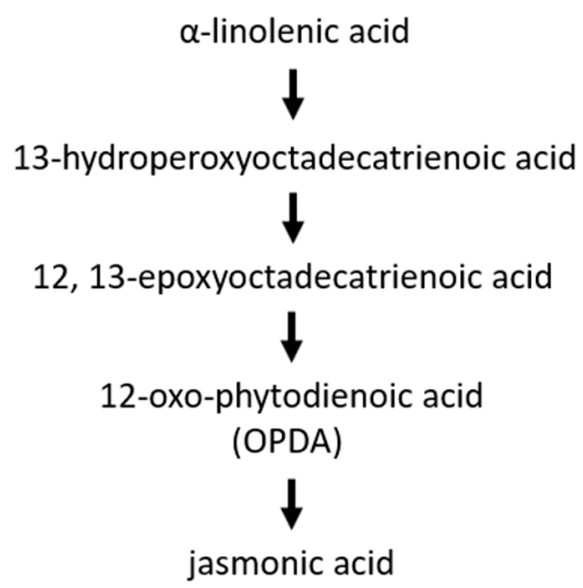

Figure 6. Jasmonic acid biosynthesis.

Activation of JA signaling is essential for plant resistance against necrotrophic pathogens [90]. While tea plants treated with laminarin, a $\beta$-glucan, show rapid accumulation of CsMAPK and CsWRKY3 as well as accumulation of high levels of SA but not $\mathrm{JA}$, induction of these two genes by $(E)$-nerolidol, a volatile signal compound, results in increased levels of JA, JA-Ile, $\mathrm{H}_{2} \mathrm{O}_{2}$ and ABA but not SA. Disease symptoms induced by C. fructicola are suppressed by JA application indicating involvement of JA in the defense of tea plants against the pathogen [50]. A qPCR study where two coffee varieties were inoculated with C. kahawae revealed that JA is earlier and stronger induced in the resistant variety indicating its role in successful activation of defense responses and inhibition of fungal growth [91] which is associated with the hypersensitive-like host cell death as well as the early accumulation of phenolic compounds in the cell walls and in the cytoplasmatic contents [92,93]. C. gloeosporioides shows enhanced virulence on tea leaves under elevated $\mathrm{CO}_{2}$ levels which also reduced the caffeine content in the leaves while exogenous caffeine application reduced size of the lesions induced by the fungus. Upon caffeine administration lipoxygenase (LOX) activity and its gene expression is elevated regardless of the $\mathrm{CO}_{2}$ level. However, in presence of fungal infection the JA content is only increased under elevated $\mathrm{CO}_{2}$ indicating the presence of a JA-independent LOX pathway in tea plants [94]. JA is also involved in the susceptibility of maize plants towards anthracnose caused by C. graminicola. Inoculation of a JA deficient double mutant, opr7opr8, with C. graminicola showed elevated resistance. Analysis of the hormones revealed enhanced levels of SA while JA levels were strongly diminished [85]. opr7opr8 are crucial for JA biosynthesis and hence play an important role in the development of plants, however, these defects can be rescued by exogenous application of JA. JA deficient mutants also show a longer lifespan of the first and the second leaf. While ET levels are comparable between the wild type and the opr7opr8 mutants in the first leaf after 12 days, ABA levels are significantly lower in the mutant leaves which is expected due to the delayed leaf senescence [95]. Jasmonic acid plays a role in resistance towards insects and necrotrophic fungal pathogens. However, several pathogens evolved mechanisms to hijack the JA pathway. For example, Pseudomonas syringae pv. Tomato secretes virulence effector protein as well as a polyketide phytotoxin to interfere with and evade the plant defense system. Also, beneficial microbes are able to hijack JA homeostasis to establish symbiotic interactions (reviewed by [96]). 


\section{Brassinosteroids}

Brassinosteroids (BRs) belong to the class of steroid plant hormones. Free BRs either contain 27,28 or 29 carbon atoms within their skeletal structure. They are either synthesized via the mevalonate or the non-mevalonate pathway which has recently been reviewed by Bajguz et al. [97]. Signaling and signal transduction have recently been reviewed as well [98]. BR signaling briefly summarized: In the absence of BRs BRI1 and BAK1 which are plasma membrane localized receptors, are inhibited by several factors including BKI1 and BIR2. BIN2 kinase phosphorylates BES1 and BZR1 transcription factors acting as a negative regulator. This results in a higher expression of BR repressed genes while BR-induced genes are hardly expressed. On the other side, in the presence of BRs, the hormone binds to the BRI1 receptor and the BAK1 co-receptor initiating the signaling cascade. This leads to the dissociation of BKI1 and BAK1 from the receptor which are further activated by phosphorylation. Next, BSKs/CDGs become phosphorylated activating BSU1 phosphatase which inhibits BIN2. After dephosphorylation of BES1 and BZR1 by PP2A, BES1 and BZR1 can interact with transcription factors and cofactors promoting BR-induced gene expression and inhibit the expression of BR-repressed genes.

BRs also play a role in the regulation of other plant hormones. Auxin response factors (ARFs) are transcriptionally regulated by BRs in a transcriptional feedback loop [99]. BIN2 mediated phosphorylation of ARF2 has been demonstrated to reduce ARF2 DNA binding and repression activities [100]. The crosstalk between gibberellins (GA) and BRs is mainly achieved through GA induced degradation of DELLA since active GAs are bound to the GIBBERELLIN INSENSITIVE DWARF1 (GID1) receptor. As a result, GID1 binds to the N-terminal region of DELLA proteins which induces their degradation via the ubiquitinproteasome pathway [101]. BRs are also involved in plant-pathogen interactions regardless of whether the interactions are biotrophic, hemibiotrophic or necrotrophic (reviewed by $[102,103])$.

Exogenously applied BRs give plants resistance or tolerance to different abiotic stresses but also induce protection against different pathogens. A study where strawberry plants were treated with 24-epibrassinolide (EP24) and a brassinosteroid spirostanic analogue DI-31 (BB16), the resistance towards C. acutatum was enhanced concomitant with increased production of $\mathrm{H}_{2} \mathrm{O}_{2}, \mathrm{O}_{2}{ }^{-}$, $\mathrm{NO}$, calcium oxalate crystals as well as higher callose and lignin deposition [104]. An RNA-seq approach with red mango fruits which were inoculated with C. gloeosporioides revealed not only upregulated ethylene related gene expression but also enhanced expression of genes belonging to the phenylpropanoid and brassinosteroid pathways [105]. BRs have also been described to induce disease resistance in Nicotiana tabacum and Oryza sativa [106]. A recently delineated link between brassinosteroid and JA signaling suggests that OsGSK2, a key suppressor of BR signaling, also enhances on one side antiviral defense but also activates JA signaling [107].

\section{Synopsis}

Plant hormones play a crucial role in plant-microbe interaction regardless whether a symbiosis is formed, a pathogen interferes with plant hormone homeostasis during infection or in the defense of the plant triggering expression of stress responsive genes. Several Colletotrichum species have been described to be capable of auxin production, however, only the metabolic intermediates have been described [61-63,80]. Understanding the contribution of auxin to virulence during Colletotrichum infection may open new opportunities for resistance breeding. Since auxin acts as growth hormone it is supposedly not contributing to stress tolerance but rather weakens the stress response of the plant. A simplified model of the contribution of different plant hormones to stress response is shown in Figure 7. 


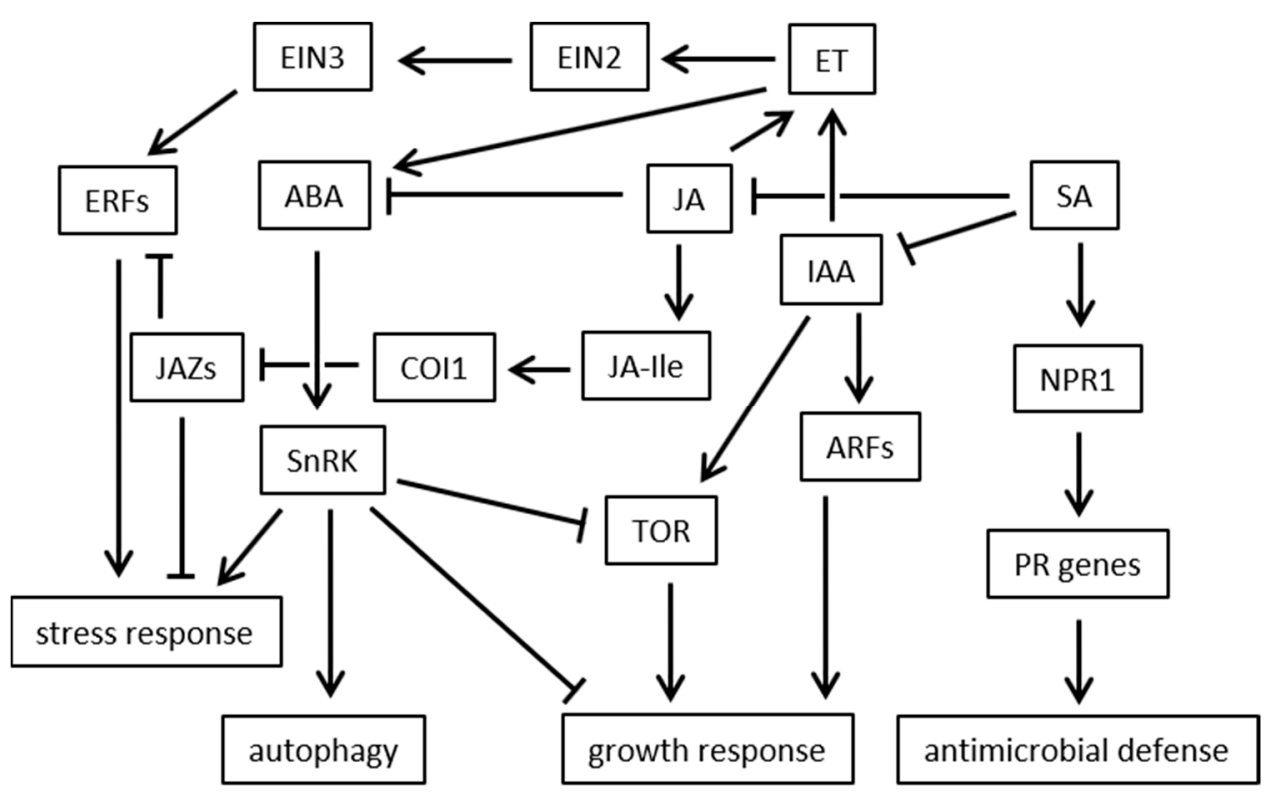

Figure 7. Simplified model of the contribution of different plant hormones to stress response; SA reduces the formation of IAA and induces the expression of non-expressor of pathogenesis related gene 1 (NPR1). Localization of the NPR monomer in the nucleus activates TGA transcription factors (TFs) which can bind pathogenesis related (PR) gene promoters and activate transcription of defense genes. JA is induced upon biotic and abiotic stresses. It is converted to the biologically active form JAIle which is perceived by its receptor COI1. COI1 triggers the degradation of JAZ repressors resulting in the release of downstream transcription factors and further induction of JA-responsive genes. JA induces ethylene formation which activates ethylene insensitive 2 (EIN2), a transmembrane protein, which further induces the transcription factor EIN3 leading to expression of ethylene response factors (ERFs) triggering the stress response. ABA induces stress response and autophagy via SNF1related protein kinase $(\mathrm{SnRK})$ which on the other side inhibits the growth response and the target of rapamycin (TOR) but promotes stress response and autophagy. Auxin leads to the activation of auxin response factors (ARFs) as well as TOR which both trigger growth response.

Many symbionts and plant pathogens have evolved the ability to interfere with plant hormone homeostasis [63,108-111]. However, the literature dealing with plantColletotrichum interaction on plant hormonal level is limited, especially the biosynthetic pathways of plant hormones in Colletotrichum and their perception. There are still many open questions from the plant hormonal perspective. In how far auxin produced by Colletotrichum boosts virulence remains to be investigated. A more detailed description of the role of auxin, ethylene, abscisic acid and other plant hormones during Colletotrichum infection may show opportunities for directed plant breeding and enhance resistance this way.

Author Contributions: Conceptualization, T.S.; writing—original draft preparation, T.S.; writingreview and editing, T.S., M.R.T. and J.S.; funding acquisition, J.S.; All authors have read and agreed to the published version of the manuscript.

Funding: Funding for this work was received through the "Special Research Area Fusarium" subproject F3703-B22 by the Austrian Science Fund FWF as well as from the FWF stand-alone project "ChroCosm", project number P32790 to JS.

Conflicts of Interest: The authors declare no conflict of interest. 


\section{References}

1. Talhinhas, P.; Sreenivasaprasad, S.; Neves-Martins, J.; Oliveira, H. Molecular and Phenotypic Analyses Reveal Association of Diverse Colletotrichum acutatum Groups and a Low Level of C. gloeosporioides with Olive Anthracnose. Appl. Environ. Microbiol. 2005, 71, 2987-2998. [CrossRef] [PubMed]

2. Sukno, S.A.; García, V.M.; Shaw, B.D.; Thon, M.R. Root Infection and Systemic Colonization of Maize by Colletotrichum graminicola. Appl. Environ. Microbiol. 2008, 74, 823-832. [CrossRef]

3. Rogério, F.; Ciampi-Guillardi, M.; Barbieri, M.C.G.; Bragança, C.A.D.; Seixas, C.D.S.; Almeida, A.M.R.; Massola, N.S. Phylogeny and Variability of Colletotrichum truncatum Associated with Soybean Anthracnose in Brazil. J. Appl. Microbiol. 2017, 122, 402-415. [CrossRef] [PubMed]

4. Xavier, K.V.; Pfeiffer, T.; Parreira, D.F.; Chopra, S.; Vaillancourt, L. Aggressiveness of Colletotrichum sublineola Strains from Sorghum bicolor and S. halepense to Sweet Sorghum Variety Sugar Drip, and Their Impact on Yield. Plant Dis. 2017, 101, 1578-1587. [CrossRef] [PubMed]

5. Wang, N.-Y.; Forcelini, B.B.; Peres, N.A. Anthracnose Fruit and Root Necrosis of Strawberry are Caused by a Dominant Species within the Colletotrichum acutatum Species Complex in the United States. Phytopathology 2019, 109, 1293-1301. [CrossRef] [PubMed]

6. Perfect, S.E.; Hughes, H.B.; O'Connell, R.J.; Green, J.R. Colletotrichum: A Model Genus for Studies on Pathology and Fungal-Plant Interactions. Fungal Genet. Biol. 1999, 27, 186-198. [CrossRef] [PubMed]

7. Münch, S.; Lingner, U.; Floss, D.S.; Ludwig, N.; Sauer, N.; Deising, H.B. The Hemibiotrophic Lifestyle of Colletotrichum Species. J. Plant Physiol. 2008, 165, 41-51. [CrossRef] [PubMed]

8. Nair, D.N.; Padmavathy, S. Impact of Endophytic Microorganisms on Plants, Environment and Humans. Sci. World J. 2014, 2014, 250693. [CrossRef]

9. Baroncelli, R.; Talhinhas, P.; Pensec, F.; Sukno, S.A.; Le Floch, G.; Thon, M.R. The Colletotrichum Acutatum Species Complex as a Model System to Study Evolution and Host Specialization in Plant Pathogens. Front. Microbiol. 2017, 8, 2001. [CrossRef] [PubMed]

10. Wang, M.; Zhou, Z.; Wu, J.; Ji, Z.; Zhang, J. Comparative Transcriptome Analysis Reveals Significant Differences in Gene Expression between Appressoria and Hyphae in Colletotrichum gloeosporioides. Gene 2018, 670, 63-69. [CrossRef]

11. Liang, X.; Shang, S.; Dong, Q.; Wang, B.; Zhang, R.; Gleason, M.L.; Sun, G. Transcriptomic Analysis Reveals Candidate Genes Regulating Development and Host Interactions of Colletotrichum fructicola. BMC Genom. 2018, 19, 557. [CrossRef]

12. O'Connell, R.J.; Thon, M.R.; Hacquard, S.; Amyotte, S.G.; Kleemann, J.; Torres, M.F.; Damm, U.; Buiate, E.A.; Epstein, L.; Alkan, N.; et al. Lifestyle Transitions in Plant Pathogenic Colletotrichum Fungi Deciphered by Genome and Transcriptome Analyses. Nat. Genet. 2012, 44, 1060-1065. [CrossRef]

13. Wang, X.; Xu, X.; Liang, Y.; Wang, Y.; Tian, C. A Cdc42 Homolog in Colletotrichum gloeosporioides Regulates Morphological Development and is Required for ROS-Mediated Plant Infection. Curr. Genet. 2018, 64, 1153-1169. [CrossRef] [PubMed]

14. Asakura, M.; Yoshino, K.; Hill, A.M.; Kubo, Y.; Sakai, Y.; Takano, Y. Primary and Secondary Metabolism Regulates Lipolysis in Appressoria of Colletotrichum orbiculare. Fungal Genet. Biol. 2012, 49, 967-975. [CrossRef] [PubMed]

15. Bari, R.; Jones, J.D.G. Role of Plant Hormones in Plant Defence Responses. Plant Mol. Biol. 2009, 69, 473-488. [CrossRef] [PubMed]

16. Nakashima, K.; Yamaguchi-Shinozaki, K. ABA Signaling in Stress-Response and Seed Development. Plant Cell Rep. 2013, 32, 959-970. [CrossRef] [PubMed]

17. Zhang, J.; Jia, W.; Yang, J.; Ismail, A.M. Role of ABA in Integrating Plant Responses to Drought and Salt Stresses. Field Crop. Res. 2006, 97, 111-119. [CrossRef]

18. Lata, C.; Prasad, M. Role of DREBs in Regulation of Abiotic Stress Responses in Plants. J. Exp. Bot. 2011, 62, 4731-4748. [CrossRef]

19. Navarro, L.; Bari, R.; Achard, P.; Lisón, P.; Nemri, A.; Harberd, N.P.; Jones, J.D.G. DELLAs Control Plant Immune Responses by Modulating the Balance of Jasmonic Acid and Salicylic Acid Signaling. Curr. Biol. 2008, 18, 650-655. [CrossRef] [PubMed]

20. Nishiyama, R.; Watanabe, Y.; Leyva-Gonzalez, M.A.; Ha, C.V.; Fujita, Y.; Tanaka, M.; Seki, M.; Yamaguchi-Shinozaki, K.; Shinozaki, K.; Herrera-Estrella, L.; et al. Arabidopsis AHP2, AHP3 and AHP5 Histidine Phosphotransfer Proteins Function as Redundant Negative Regulators of Drought Stress Response. Proc. Natl. Acad. Sci. USA 2013, 110, 4840-4845. [CrossRef] [PubMed]

21. de Jesus Miranda, V.; Porto, W.F.; da Rocha Fernandes, G.; Pogue, R.; Nolasco, D.O.; Araujo, A.C.G.; Cota, L.V.; de Freitas, C.G.; Dias, S.C.; Franco, O.L. Comparative Transcriptomic Analysis Indicates Genes Associated with Local and Systemic Resistance to Colletotrichum graminicola in Maize. Sci. Rep. 2017, 7, 2483. [CrossRef]

22. Padder, B.A.; Kamfwa, K.; Awale, H.E.; Kelly, J.D. Transcriptome Profiling of the Phaseolus vulgaris—Colletotrichum lindemuthianum Pathosystem. PLoS ONE 2016, 11, e0165823. [CrossRef]

23. Wang, F.; Zhang, F.; Chen, M.; Liu, Z.; Zhang, Z.; Fu, J.; Ma, Y. Comparative Transcriptomics Reveals Differential Gene Expression Related to Colletotrichum gloeosporioides Resistance in the Octoploid Strawberry. Front. Plant Sci. 2017, 8, 779. [CrossRef] [PubMed]

24. Hong, K.; Gong, D.; Zhang, L.; Hu, H.; Jia, Z.; Gu, H.; Song, K. Transcriptome Characterization and Expression Profiles of the Related Defense Genes in Postharvest Mango Fruit against Colletotrichum gloeosporioides. Gene 2016, 576, 275-283. [CrossRef]

25. Johnson, P.R.; Ecker, J.R. The Ethylene Gas Signal Transduction Pathway: A Molecular Perspective. Annu. Rev. Genet. 1998, 32, 227-254. [CrossRef]

26. Adams, D.O.; Yang, S.F. Ethylene Biosynthesis: Identification of 1-Aminocyclopropane-1-Carboxylic Acid as an Intermediate in the Conversion of Methionine to Ethylene. Proc. Natl. Acad. Sci. USA 1979, 76, 170-174. [CrossRef] 
27. Fukuda, H.; Takahashi, M.; Fujii, T.; Tazaki, M.; Ogawa, T. An NADH:Fe(III)EDTA Oxidoreductase from Cryptococcus Albidus: An Enzyme Involved in Ethylene Production in vivo? FEMS Microbiol. Lett. 1989, 51, 107-111. [CrossRef]

28. Young, R.E.; Pratt, H.K.; Biale, J.B. Identification of Ethylene as a Volatile Product of the Fungus Penicillium digitatum. Plant Physiol. 1951, 26, 304-310. [CrossRef] [PubMed]

29. Jacobsen, D.W.; Wang, C.H. The Biogenesis of Ethylene in Penicillium digitatum. Plant Physiol. 1968, 43, 1959-1966. [CrossRef] [PubMed]

30. Nagahama, K.; Ogawa, T.; Fujii, T.; Tazaki, M.; Tanase, S.; Morino, Y.; Fukuda, H. Purification and Properties of an EthyleneForming Enzyme from Pseudomonas syringae Pv. Phaseolicola PK2. J. Gen. Microbiol. 1991, 137, 2281-2286. [CrossRef]

31. Etesami, H.; Maheshwari, D.K. Use of Plant Growth Promoting Rhizobacteria (PGPRs) with Multiple Plant Growth Promoting Traits in Stress Agriculture: Action Mechanisms and Future Prospects. Ecotoxicol. Environ. Saf. 2018, 156, 225-246. [CrossRef]

32. Svoboda, T.; Parich, A.; Güldener, U.; Schöfbeck, D.; Twaruschek, K.; Václavíková, M.; Hellinger, R.; Wiesenberger, G.; Schuhmacher, R.; Adam, G. Biochemical Characterization of the Fusarium graminearum Candidate ACC-Deaminases and Virulence Testing of Knockout Mutant Strains. Front. Plant Sci. 2019, 10, 1072. [CrossRef] [PubMed]

33. Ali, S.; Hameed, S.; Shahid, M.; Iqbal, M.; Lazarovits, G.; Imran, A. Functional Characterization of Potential PGPR Exhibiting Broad-Spectrum Antifungal Activity. Microbiol. Res. 2020, 232, 126389. [CrossRef]

34. Mishra, R.; Mohanty, J.N.; Chand, S.K.; Joshi, R.K. Can-MiRn37a Mediated Suppression of Ethylene Response Factors Enhances the Resistance of Chilli against Anthracnose Pathogen Colletotrichum truncatum L. Plant Sci. 2018, 267, 135-147. [CrossRef]

35. Moyano-Cañete, E.; Bellido, M.L.; García-Caparrós, N.; Medina-Puche, L.; Amil-Ruiz, F.; González-Reyes, J.A.; Caballero, J.L.; Muñoz-Blanco, J.; Blanco-Portales, R. FaGAST2, a Strawberry Ripening-Related Gene, Acts Together with FaGAST1 to Determine Cell Size of the Fruit Receptacle. Plant Cell Physiol. 2013, 54, 218-236. [CrossRef]

36. Chen, X.; Steed, A.; Travella, S.; Keller, B.; Nicholson, P. Fusarium graminearum Exploits Ethylene Signalling to Colonize Dicotyledonous and Monocotyledonous Plants. New Phytol. 2009, 182, 975-983. [CrossRef] [PubMed]

37. Chen, N.; Goodwin, P.H.; Hsiang, T. The Role of Ethylene during the Infection of Nicotiana Tabacum by Colletotrichum destructivum. J. Exp. Bot. 2003, 54, 2449-2456. [CrossRef]

38. Daundasekera, M.; Joyce, D.C.; Aked, J.; Adikaram, N.K.B. Ethylene Production by Colletotrichum musae in vitro. Physiol. Mol. Plant Pathol. 2003, 62, 21-28. [CrossRef]

39. Liu, X.; Li, B.; Yang, Y.; Cai, J.; Shi, T.; Zheng, X.; Huang, G. Pathogenic Adaptations Revealed by Comparative Genome Analyses of Two Colletotrichum spp., the Causal Agent of Anthracnose in Rubber Tree. Front. Microbiol. 2020, 11, 1484. [CrossRef] [PubMed]

40. Kleemann, J.; Rincon-Rivera, L.J.; Takahara, H.; Neumann, U.; van Themaat, E.V.L.; van der Does, H.C.; Hacquard, S.; Stüber, K.; Will, I.; Schmalenbach, W.; et al. Sequential Delivery of Host-Induced Virulence Effectors by Appressoria and Intracellular Hyphae of the Phytopathogen Colletotrichum higginsianum. PLoS Pathog. 2012, 8, e1002643. [CrossRef]

41. Hauser, F.; Waadt, R.; Schroeder, J.I. Evolution of Abscisic Acid Synthesis and Signaling Mechanisms. Curr. Biol. 2011, 21, R346-R355. [CrossRef]

42. Lievens, L.; Pollier, J.; Goossens, A.; Beyaert, R.; Staal, J. Abscisic Acid as Pathogen Effector and Immune Regulator. Front. Plant Sci. 2017, 8, 587. [CrossRef] [PubMed]

43. Chen, K.; Li, G.-J.; Bressan, R.A.; Song, C.-P.; Zhu, J.-K.; Zhao, Y. Abscisic Acid Dynamics, Signaling, and Functions in Plants. J. Integr. Plant. Biol. 2020, 62, 25-54. [CrossRef]

44. Patkar, R.N.; Naqvi, N.I. Fungal Manipulation of Hormone-Regulated Plant Defense. PLoS Pathog. 2017, 13, e1006334. [CrossRef]

45. Xu, G.; Yang, S.; Meng, L.; Wang, B.-G. The Plant Hormone Abscisic Acid Regulates the Growth and Metabolism of Endophytic Fungus Aspergillus nidulans. Sci. Rep. 2018, 8, 6504. [CrossRef]

46. Hwang, S.K.; Kim, J.H.; Kim, Y.H.; Kim, H.T. ABA Increases Susceptibility of Pepper Fruits to Infection of Anthracnose by Collectotrichum acutatum. Plant Pathol. J. 2008, 24, 400-406. [CrossRef]

47. Wang, L.; Wang, Y.; Cao, H.; Hao, X.; Zeng, J.; Yang, Y.; Wang, X. Transcriptome Analysis of an Anthracnose-Resistant Tea Plant Cultivar Reveals Genes Associated with Resistance to Colletotrichum camelliae. PLoS ONE 2016, 11, e0148535. [CrossRef] [PubMed]

48. Mayek-PÉrez, N.; Garcĺa-Espinosa, R.; LÓpez-CastaÑeda, C.; Acosta-Gallegos, J.A.; Simpson, J. Water Relations, Histopathology and Growth of Common Bean (Phaseolus vulgaris L.) during Pathogenesis of Macrophomina phaseolina under Drought Stress. Physiol. Mol. Plant Pathol. 2002, 60, 185-195. [CrossRef]

49. Ghassemian, M.; Nambara, E.; Cutler, S.; Kawaide, H.; Kamiya, Y.; McCourt, P. Regulation of Abscisic Acid Signaling by the Ethylene Response Pathway in Arabidopsis. Plant Cell 2000, 12, 1117-1126. [CrossRef] [PubMed]

50. Chen, S.; Zhang, L.; Cai, X.; Li, X.; Bian, L.; Luo, Z.; Li, Z.; Chen, Z.; Xin, Z. (E)-Nerolidol is a Volatile Signal that Induces Defenses against Insects and Pathogens in Tea Plants. Hortic. Res. 2020, 7, 52. [CrossRef]

51. Ramos-Puebla, A.; De Santiago, C.; Trombotto, S.; David, L.; Larralde-Corona, C.P.; Shirai, K. Addition of Abscisic Acid Increases the Production of Chitin Deacetylase by Colletotrichum gloeosporioides in Submerged Culture. Process Biochem. 2016, 51, 959-966. [CrossRef]

52. Pacheco, N.; Trombotto, S.; David, L.; Shirai, K. Activity of Chitin Deacetylase from Colletotrichum gloeosporioides on Chitinous Substrates. Carbohydr. Polym. 2013, 96, 227-232. [CrossRef]

53. Shrestha, B.; Blondeau, K.; Stevens, W.F.; Hegarat, F.L. Expression of Chitin Deacetylase from Colletotrichum lindemuthianum in Pichia Pastoris: Purification and Characterization. Protein Expr. Purif. 2004, 38, 196-204. [CrossRef] [PubMed] 
54. Tsigos, I.; Bouriotis, V. Purification and Characterization of Chitin Deacetylase from Colletotrichum lindemuthianum. J. Biol. Chem. 1995, 270, 26286-26291. [CrossRef] [PubMed]

55. Gao, F.; Zhang, B.-S.; Zhao, J.-H.; Huang, J.-F.; Jia, P.-S.; Wang, S.; Zhang, J.; Zhou, J.-M.; Guo, H.-S. Deacetylation of Chitin Oligomers Increases Virulence in Soil-Borne Fungal Pathogens. Nat. Plants 2019, 5, 1167-1176. [CrossRef] [PubMed]

56. Langner, T.; Göhre, V. Fungal Chitinases: Function, Regulation and Potential Roles in Plant/Pathogen Interactions. Curr. Genet. 2016, 62, 243-254. [CrossRef]

57. Ali, M.; Li, Q.-H.; Zou, T.; Wei, A.-M.; Gombojav, G.; Lu, G.; Gong, Z.-H. Chitinase Gene Positively Regulates Hypersensitive and Defense Responses of Pepper to Colletotrichum acutatum Infection. Int. J. Mol. Sci. 2020, 21, 6624. [CrossRef] [PubMed]

58. Limon, T.; Birke, A.; Monribot-Villanueva, J.L.; Guerrero-Analco, J.A.; Altúzar-Molina, A.; Carrión, G.; Goycoolea, F.M.; Moerschbacher, B.M.; Aluja, M. Chitosan Coatings Reduce Fruit Fly (Anastrepha obliqua) Infestation and Development of the Fungus Colletotrichum gloeosporioides in Manila Mangoes. J. Sci. Food Agric. 2021, 101, 2756-2766. [CrossRef] [PubMed]

59. Morffy, N.; Strader, L.C. Old Town Roads: Routes of Auxin Biosynthesis across Kingdoms. Curr. Opin. Plant Biol. 2020, 55, 21-27. [CrossRef]

60. Robinson, M.; Riov, J.; Sharon, A. Indole-3-Acetic Acid Biosynthesis in Colletotrichum gloeosporioides f. sp. Aeschynomene. Appl. Environ. Microbiol. 1998, 64, 5030-5032. [CrossRef]

61. Lu, H.; Zou, W.X.; Meng, J.C.; Hu, J.; Tan, R.X. New Bioactive Metabolites Produced by Colletotrichum Sp., an Endophytic Fungus in Artemisia annua. Plant Sci. 2000, 151, 67-73. [CrossRef]

62. Chung, K.R.; Shilts, T.; Ertürk, U.; Timmer, L.W.; Ueng, P.P. Indole Derivatives Produced by the Fungus Colletotrichum acutatum Causing Lime Anthracnose and Postbloom Fruit Drop of Citrus. FEMS Microbiol. Lett. 2003, 226, 23-30. [CrossRef]

63. Numponsak, T.; Kumla, J.; Suwannarach, N.; Matsui, K.; Lumyong, S. Biosynthetic Pathway and Optimal Conditions for the Production of Indole-3-Acetic Acid by an Endophytic Fungus, Colletotrichum fructicola CMU-A109. PLoS ONE 2018, 13, e0205070. [CrossRef]

64. Chanclud, E.; Morel, J.-B. Plant Hormones: A Fungal Point of View. Mol. Plant Pathol. 2016, 17, 1289-1297. [CrossRef]

65. Benjamins, R.; Scheres, B. Auxin: The Looping Star in Plant Development. Annu. Rev. Plant Biol. 2008, 59, 443-465. [CrossRef] [PubMed]

66. Maor, R.; Haskin, S.; Levi-Kedmi, H.; Sharon, A. In Planta Production of Indole-3-Acetic Acid by Colletotrichum Gloeosporioides f. sp. Aeschynomene. Appl. Environ. Microbiol. 2004, 70, 1852-1854. [CrossRef] [PubMed]

67. Cohen, B.A.; Amsellem, Z.; Maor, R.; Sharon, A.; Gressel, J. Transgenically Enhanced Expression of Indole-3-Acetic Acid Confers Hypervirulence to Plant Pathogens. Phytopathology 2002, 92, 590-596. [CrossRef]

68. Zhang, L.; Huang, X.; He, C.; Zhang, Q.-Y.; Zou, X.; Duan, K.; Gao, Q. Novel Fungal Pathogenicity and Leaf Defense Strategies are Revealed by Simultaneous Transcriptome Analysis of Colletotrichum fructicola and Strawberry Infected by this Fungus. Front. Plant Sci. 2018, 9, 434. [CrossRef]

69. Lu, Q.; Wang, Y.; Xiong, F.; Hao, X.; Zhang, X.; Li, N.; Wang, L.; Zeng, J.; Yang, Y.; Wang, X. Integrated Transcriptomic and Metabolomic Analyses Reveal the Effects of Callose Deposition and Multihormone Signal Transduction Pathways on the Tea Plant-Colletotrichum camelliae Interaction. Sci. Rep. 2020, 10, 12858. [CrossRef] [PubMed]

70. Jeyaraj, A.; Wang, X.; Wang, S.; Liu, S.; Zhang, R.; Wu, A.; Wei, C. Identification of Regulatory Networks of MicroRNAs and Their Targets in Response to Colletotrichum gloeosporioides in Tea Plant (Camellia sinensis L.). Front. Plant Sci. 2019, 10, 1096. [CrossRef]

71. Kurepa, J.; Shull, T.E.; Karunadasa, S.S.; Smalle, J.A. Modulation of Auxin and Cytokinin Responses by Early Steps of the Phenylpropanoid Pathway. BMC Plant Biol. 2018, 18, 278. [CrossRef]

72. Wildermuth, M.C.; Dewdney, J.; Wu, G.; Ausubel, F.M. Isochorismate Synthase is Required to Synthesize Salicylic Acid for Plant Defence. Nature 2001, 414, 562-565. [CrossRef] [PubMed]

73. Shi, Y.-L.; Sheng, Y.-Y.; Cai, Z.-Y.; Yang, R.; Li, Q.-S.; Li, X.-M.; Li, D.; Guo, X.-Y.; Lu, J.-L.; Ye, J.-H.; et al. Involvement of Salicylic Acid in Anthracnose Infection in Tea Plants Revealed by Transcriptome Profiling. Int. J. Mol. Sci. 2019, 20, 2439. [CrossRef]

74. Shine, M.B.; Xiao, X.; Kachroo, P.; Kachroo, A. Signaling Mechanisms Underlying Systemic Acquired Resistance to Microbial Pathogens. Plant Sci. 2019, 279, 81-86. [CrossRef] [PubMed]

75. Vlot, A.C.; Liu, P.-P.; Cameron, R.K.; Park, S.-W.; Yang, Y.; Kumar, D.; Zhou, F.; Padukkavidana, T.; Gustafsson, C.; Pichersky, E.; et al. Identification of Likely Orthologs of Tobacco Salicylic Acid-Binding Protein 2 and Their Role in Systemic Acquired Resistance in Arabidopsis Thaliana. Plant J. 2008, 56, 445-456. [CrossRef]

76. Amil-Ruiz, F.; Garrido-Gala, J.; Gadea, J.; Blanco-Portales, R.; Muñoz-Mérida, A.; Trelles, O.; de los Santos, B.; Arroyo, F.T.; Aguado-Puig, A.; Romero, F.; et al. Partial Activation of SA- and JA-Defensive Pathways in Strawberry upon Colletotrichum acutatum Interaction. Front. Plant Sci. 2016, 7, 1036. [CrossRef] [PubMed]

77. Aoi, Y.; Tanaka, K.; Cook, S.D.; Hayashi, K.-I.; Kasahara, H. GH3 Auxin-Amido Synthetases Alter the Ratio of Indole-3-Acetic Acid and Phenylacetic Acid in Arabidopsis. Plant Cell Physiol. 2020, 61, 596-605. [CrossRef]

78. Wang, D.; Pajerowska-Mukhtar, K.; Culler, A.H.; Dong, X. Salicylic Acid Inhibits Pathogen Growth in Plants through Repression of the Auxin Signaling Pathway. Curr. Biol. 2007, 17, 1784-1790. [CrossRef]

79. Zhang, Z.; Li, Q.; Li, Z.; Staswick, P.E.; Wang, M.; Zhu, Y.; He, Z. Dual Regulation Role of GH3.5 in Salicylic Acid and Auxin Signaling during Arabidopsis-Pseudomonas Syringae Interaction. Plant Physiol. 2007, 145, 450-464. [CrossRef] 
80. Lahey, K.A.; Yuan, R.; Burns, J.K.; Ueng, P.P.; Timmer, L.W.; Kuang-Ren, C. Induction of Phytohormones and Differential Gene Expression in Citrus Flowers Infected by the Fungus Colletotrichum acutatum. Mol. Plant Microbe Interact. 2004, 17, $1394-1401$. [CrossRef]

81. Zhang, Q.-Y.; Zhang, L.-Q.; Song, L.-L.; Duan, K.; Li, N.; Wang, Y.-X.; Gao, Q.-H. The Different Interactions of Colletotrichum gloeosporioides with Two Strawberry Varieties and the Involvement of Salicylic Acid. Hortic. Res. 2016, 3, 16007. [CrossRef] [PubMed]

82. Hayat, Q.; Hayat, S.; Irfan, M.; Ahmad, A. Effect of Exogenous Salicylic Acid under Changing Environment: A Review. Environ. Exp. Bot. 2010, 68, 14-25. [CrossRef]

83. Yoosomboon, P.; Sojikul, P.; Viboonjun, U.; Narangajavana, J. Salicylic Acid-Induced Syntaxin Gene Expression Coexists with Enhanced Resistance against Colletotrichum gloeosporioides Infection in Cassava. Trop. Plant Biol. 2021, 14, 50-62. [CrossRef]

84. Sangpueak, R.; Phansak, P.; Thumanu, K.; Siriwong, S.; Wongkaew, S.; Buensanteai, N. Effect of Salicylic Acid Formulations on Induced Plant Defense against Cassava Anthracnose Disease. Plant Pathol. J. 2021, 37, 356-364. [CrossRef] [PubMed]

85. Gorman, Z.; Christensen, S.A.; Yan, Y.; He, Y.; Borrego, E.; Kolomiets, M.V. Green Leaf Volatiles and Jasmonic Acid Enhance Susceptibility to Anthracnose Diseases Caused by Colletotrichum graminicola in Maize. Mol. Plant Pathol. 2020, 21, 702-715. [CrossRef]

86. He, C.; Duan, K.; Zhang, L.; Zhang, L.; Song, L.; Yang, J.; Zou, X.; Wang, Y.; Gao, Q. Fast Quenching the Burst of Host Salicylic Acid is Common in Early Strawberry/Colletotrichum fructicola Interaction. Phytopathology 2019, 109, 531-541. [CrossRef] [PubMed]

87. Gebauer, P.; Korn, M.; Engelsdorf, T.; Sonnewald, U.; Koch, C.; Voll, L.M. Sugar Accumulation in Leaves of Arabidopsis Sweet11/Sweet12 Double Mutants Enhances Priming of the Salicylic Acid-Mediated Defense Response. Front. Plant Sci. 2017, 8, 1378. [CrossRef]

88. Kubota, M.; Nishi, K. Salicylic Acid Accumulates in the Roots and Hypocotyl after Inoculation of Cucumber Leaves with Colletotrichum lagenarium. J. Plant Physiol. 2006, 163, 1111-1117. [CrossRef]

89. Wasternack, C.; Strnad, M. Jasmonates: News on Occurrence, Biosynthesis, Metabolism and Action of an Ancient Group of Signaling Compounds. Int. J. Mol. Sci. 2018, 19, 2539. [CrossRef] [PubMed]

90. Zhang, S.; Li, X.; Sun, Z.; Shao, S.; Hu, L.; Ye, M.; Zhou, Y.; Xia, X.; Yu, J.; Shi, K. Antagonism between Phytohormone Signalling Underlies the Variation in Disease Susceptibility of Tomato Plants under Elevated CO2. J. Exp. Bot. 2015, 66, 1951-1963. [CrossRef]

91. Diniz, I.; Figueiredo, A.; Loureiro, A.; Batista, D.; Azinheira, H.; Várzea, V.; Pereira, A.P.; Gichuru, E.; Moncada, P.; GuerraGuimarães, L.; et al. A First Insight into the Involvement of Phytohormones Pathways in Coffee Resistance and Susceptibility to Colletotrichum kahawae. PLoS ONE 2017, 12, e0178159. [CrossRef] [PubMed]

92. Loureiro, A.; Nicole, M.R.; Várzea, V.; Moncada, P.; Bertrand, B.; Silva, M.C. Coffee Resistance to Colletotrichum Kahawae is Associated with Lignification, Accumulation of Phenols and Cell Death at Infection Sites. Physiol. Mol. Plant Pathol. 2012, 77, 23-32. [CrossRef]

93. Silva, M.D.C.; Várzea, V.; Guerra-Guimarães, L.; Azinheira, H.G.; Fernandez, D.; Petitot, A.-S.; Bertrand, B.; Lashermes, P.; Nicole, M. Coffee resistance to the main diseases: Leaf rust and coffee berry disease. Braz. J. Plant Physiol. 2006, 18, 119-147. [CrossRef]

94. Li, X.; Ahammed, G.J.; Li, Z.; Tang, M.; Yan, P.; Han, W. Decreased Biosynthesis of Jasmonic Acid via Lipoxygenase Pathway Compromised Caffeine-Induced Resistance to Colletotrichum gloeosporioides Under Elevated CO2 in Tea Seedlings. Phytopathology 2016, 106, 1270-1277. [CrossRef] [PubMed]

95. Yan, Y.; Christensen, S.; Isakeit, T.; Engelberth, J.; Meeley, R.; Hayward, A.; Emery, R.J.N.; Kolomiets, M.V. Disruption of OPR7 and OPR8 Reveals the Versatile Functions of Jasmonic Acid in Maize Development and Defense. Plant Cell 2012, 24, 1420-1436. [CrossRef]

96. Yan, C.; Xie, D. Jasmonate in Plant Defence: Sentinel or Double Agent? Plant Biotechnol. J. 2015, 13, 1233-1240. [CrossRef]

97. Bajguz, A.; Chmur, M.; Gruszka, D. Comprehensive Overview of the Brassinosteroid Biosynthesis Pathways: Substrates, Products, Inhibitors and Connections. Front. Plant Sci. 2020, 11, 1034. [CrossRef]

98. Nolan, T.M.; Vukašinović, N.; Liu, D.; Russinova, E.; Yin, Y. Brassinosteroids: Multidimensional Regulators of Plant Growth, Development, and Stress Responses [OPEN]. Plant Cell 2020, 32, 295-318. [CrossRef]

99. Jung, J.-H.; Lee, M.; Park, C.-M. A Transcriptional Feedback Loop Modulating Signaling Crosstalks between Auxin and Brassinosteroid in Arabidopsis. Mol. Cells 2010, 29, 449-456. [CrossRef]

100. Vert, G.; Walcher, C.L.; Chory, J.; Nemhauser, J.L. Integration of Auxin and Brassinosteroid Pathways by Auxin Response Factor 2. Proc. Natl. Acad. Sci. USA 2008, 105, 9829-9834. [CrossRef]

101. Davière, J.-M.; Achard, P. Gibberellin Signaling in Plants. Development 2013, 140, 1147-1151. [CrossRef] [PubMed]

102. Yu, M.-H.; Zhao, Z.-Z.; He, J.-X. Brassinosteroid Signaling in Plant-Microbe Interactions. Int. J. Mol. Sci. 2018, 19, 4091. [CrossRef] [PubMed]

103. Nolan, T.; Chen, J.; Yin, Y. Cross-Talk of Brassinosteroid Signaling in Controlling Growth and Stress Responses. Biochem. J. 2017, 474, 2641-2661. [CrossRef]

104. Furio, R.N.; Albornoz, P.L.; Coll, Y.; Zamora, G.M.M.; Salazar, S.M.; Martos, G.G.; Ricci, J.C.D. Effect of Natural and Synthetic Brassinosteroids on Strawberry Immune Response against Colletotrichum acutatum. Eur. J. Plant Pathol. 2019, 153, 167-181. [CrossRef] 
105. Sudheeran, P.K.; Sela, N.; Carmeli-Weissberg, M.; Ovadia, R.; Panda, S.; Feygenberg, O.; Maurer, D.; Oren-Shamir, M.; Aharoni, A.; Alkan, N. Induced Defense Response in Red Mango Fruit against Colletotrichum gloeosporioides. Hortic. Res. 2021, 8, 17. [CrossRef] [PubMed]

106. Nakashita, H.; Yasuda, M.; Nitta, T.; Asami, T.; Fujioka, S.; Arai, Y.; Sekimata, K.; Takatsuto, S.; Yamaguchi, I.; Yoshida, S. Brassinosteroid Functions in a Broad Range of Disease Resistance in Tobacco and Rice. Plant J. 2003, 33, 887-898. [CrossRef]

107. He, Y.; Hong, G.; Zhang, H.; Tan, X.; Li, L.; Kong, Y.; Sang, T.; Xie, K.; Wei, J.; Li, J.; et al. The OsGSK2 Kinase Integrates Brassinosteroid and Jasmonic Acid Signaling by Interacting with OsJAZ4. Plant Cell 2020, 32, 2806-2822. [CrossRef]

108. Izquierdo-Bueno, I.; González-Rodríguez, V.E.; Simon, A.; Dalmais, B.; Pradier, J.-M.; Le Pêcheur, P.; Mercier, A.; Walker, A.-S.; Garrido, C.; Collado, I.G.; et al. Biosynthesis of Abscisic Acid in Fungi: Identification of a Sesquiterpene Cyclase as the Key Enzyme in Botrytis cinerea. Environ. Microbiol. 2018, 20, 2469-2482. [CrossRef]

109. Luo, K.; Rocheleau, H.; Qi, P.-F.; Zheng, Y.-L.; Zhao, H.-Y.; Ouellet, T. Indole-3-Acetic Acid in Fusarium graminearum: Identification of Biosynthetic Pathways and Characterization of Physiological Effects. Fungal Biol. 2016, 120, 1135-1145. [CrossRef]

110. Oliw, E.H.; Hamberg, M. An Allene Oxide and 12-Oxophytodienoic Acid Are Key Intermediates in Jasmonic Acid Biosynthesis by Fusarium oxysporum. J. Lipid Res. 2017, 58, 1670-1680. [CrossRef]

111. Singh, R.P.; Shelke, G.M.; Kumar, A.; Jha, P.N. Biochemistry and Genetics of ACC Deaminase: A Weapon to "Stress Ethylene" Produced in Plants. Front. Microbiol. 2015, 6, 937. [CrossRef] [PubMed] 